University of Nebraska - Lincoln

DigitalCommons@University of Nebraska - Lincoln

Faculty Publications: Department of Teaching, Department of Teaching, Learning and Teacher Learning and Teacher Education

Education

$1-2006$

\title{
Secondary Teacher Attitudes toward Including English-Language Learners in Mainstream Classrooms
}

Jenelle Reeves

University of Nebraska-Lincoln, jreeves2@unl.edu

Follow this and additional works at: https://digitalcommons.unl.edu/teachlearnfacpub

Part of the Teacher Education and Professional Development Commons

Reeves, Jenelle, "Secondary Teacher Attitudes toward Including English-Language Learners in Mainstream Classrooms" (2006). Faculty Publications: Department of Teaching, Learning and Teacher Education. 116.

https://digitalcommons.unl.edu/teachlearnfacpub/116

This Article is brought to you for free and open access by the Department of Teaching, Learning and Teacher Education at DigitalCommons@University of Nebraska - Lincoln. It has been accepted for inclusion in Faculty Publications: Department of Teaching, Learning and Teacher Education by an authorized administrator of DigitalCommons@University of Nebraska - Lincoln. 
Published in the Journal of Educational Research (January-February 2006) 99(3). Copyright 2006, Taylor \& Francis. Used by permission.

\title{
Secondary Teacher Attitudes toward Including English-Language Learners in Mainstream Classrooms
}

\author{
Jenelle R. Reeves, University of Nebraska-Lincoln, jreeves2@unl.edu
}

\begin{abstract}
Researchers have given limited attention to teacher attitudes toward inclusion of English-language learners (ELLs) in mainstream classrooms. The author explored four categories within secondary teacher attitudes toward ELL inclusion: (a) ELL inclusion, (b) coursework modification for ELLS, (c) professional development for working with ELLs, and (d) perceptions of language and language learning. Findings from a survey of 279 subject-area high school teachers indicate a neutral to slightly positive attitude toward ELL inclusion, a somewhat positive attitude toward coursework modification, a neutral attitude toward professional development for working with ELLs, and educator misconceptions regarding how second languages are learned.
\end{abstract}

Key words: English-language learners; ELLs; Mainstream classrooms; Secondary teacher attitudes

Public school teachers throughout the United States are working with an ever-increasing number of English-language learners (ELLs). From 1995 to 2001, the population of students identified as limited English proficient (LEP) grew approximately 105\% nationwide (Kindler, 2002). An estimated 4.5 million LEP students are currently enrolled in K-12 public schools in the United States. Furthermore, census projections estimate continued linguistic diversification in the coming decades (U.S. Census Bureau, 2000). Because the student population is experiencing a linguistic shift, education research set in multilingual classrooms has become a high priority, and researchers have explored the perspective of ELLs (Cummins, 2000; Fu, 1995; Harklau, 1994, 1999, 2000; Lucas, 1997; Lucas, Henze, \& Donato, 1990; Mace-Matluck, Alexander-Kasparik, \& Queen, 1998; Valdes, 2001; Walqui, 2000). Others have chronicled the professional lives of English-asa-second-language (ESL) teachers (Creese, 2002; Johnson, 1999; Johnson \& Golombek, 2002). Markedly absent in the research are mainstream teacher perspectives on ELL inclusion. The experiences of secondary teachers, in particular, have received little research attention. I designed this study to help redress the paucity of research by examining secondary mainstream teacher attitudes and perceptions of ELL inclusion.
Secondary ELLs, particularly those in schools with small ELL populations, typically spend the majority of the school day in mainstream ${ }^{1}$ classes and attend ESL classes for one or two periods. Yet, teachers in those mainstream classrooms are largely untrained to work with ELLs; only $12.5 \%$ of U.S. teachers have received 8 or more hours of recent training to teach students of limited English proficiency (National Center for Education Statistics, 2002). Unfortunately, little is known about how an underprepared teaching force is coping with its increasingly linguistically diverse classrooms.

Some preliminary research into teachers' views of linguistically diverse schools is available. Although subjectarea ${ }^{2}$ teachers of ELLs have rarely been the primary focus of research attention, their attitudes toward ELL inclusion have been alluded to in a number of studies (Fu, 1995; Harklau, 2000; Olsen, 1997; Schmidt, 2000; Valdes, 1998, 2001; Verplaetse, 1998; Vollmer, 2000) in linguistically diverse classrooms. The portraits of teachers in those studies, although incomplete, grant at least limited insight into teacher experiences with ELLs. Commonalities and recurring themes exist in the preliminary studies, including teachers' (a) attitudes toward ELL inclusion in mainstream classes, (b) views on modification of coursework, and (c) feelings of (un)preparedness to work with ELLs.

Attitudes toward Inclusion

Several qualitative studies exploring the schooling experiences of ELLs have alluded to mainstream teacher attitudes toward ELL inclusion. Teachers in those studies were portrayed as holding negative, unwelcoming attitudes (Fu, 1995; Olsen, 1997; Schmidt, 2000; Valdes, 1998, 2001), as well as positive, welcoming attitudes (Harklau, 2000; Reeves, 2004; Verplaetse, 1998). In general, teachers in those studies held ambivalent or unwelcoming attitudes, although there were notable exceptions (Harklau; Verplaetse). In determining the welcoming or unwelcoming nature of teacher attitudes, researchers suggested a host of factors that could be influential. The factors fall into three categories: (a) teacher perceptions of the impact of ELL inclusion on themselves, (b) impact of inclusion on the learning environment, and (c) teacher attitudes and perceptions of ELLs. 
Research suggests that teachers may be concerned about (a) chronic lack of time to address ELLs' unique classroom needs (Youngs, 1999), (b) perceived intensification of teacher workloads when ELLs are enrolled in mainstream classes (Gitlin, Buenda, Crosland, \& Doumbia, 2003), and (c) feelings of professional inadequacy to work with ELLs (Verplaetse, 1998). In terms of the impact of inclusion on the classroom learning environment, teachers are concerned about the possibility that ELLs will slow the class progression through the curriculum (Youngs) or result in inequities in educational opportunities for all students (Platt, Harper, \& Mendoza, 2003; Reeves, 2004; Schmidt, 2000). Finally, some evidence of subject-area teacher attitudes and perceptions of ELLs is present in research, including a reluctance to work with low-proficiency ELLs (Platt et al.), misconceptions about the processes of second-language acquisition (Olsen, 1997; Reeves, 2004; Walqui, 2000), and assumptions (positive and negative) about the race and ethnicity of ELLs (Harklau, 2000; Valdes, 2001; Vollmer, 2000).

All of the studies listed in the preceding paragraph were qualitative and had a small number of teacher participants; few held mainstream teachers as the primary focus of study. In their quantitative study of 143 middle school teachers, however, Youngs and Youngs (2001) focused exclusively on mainstream teacher attitudes. In a survey of participants, the researchers found that teacher attitudes were neutral to slightly positive in response to the following two questions: (a) "If you were told that you could expect two or three ESL students in one of your classes next year, how would you describe your reaction?" and (b) "How would you describe your overall reaction to working with ESL students in your classroom?" (p. 108). Youngs and Youngs also correlated five factors to teachers' positive attitudes: (a) coursework in foreign language/multiculturalism, (b) ESL training, (c) personal experience with foreign cultures, (d) contact with a diversity of ESL students, and (e) female gender. Beyond the research of Youngs and Youngs, quantitative measures of teacher attitudes are scarce.

\section{Attitudes toward Modifications}

Inclusion as a model for addressing the needs of ELLs has gained popularity as the nation's emphasis on standards and accountability has increased. In an inclusion model, ELLs might receive ESL courses, but the students are mainstreamed for most, if not all, of the school day. ELLs placed exclusively in courses designed for LEP students (i.e., ESL and sheltered instruction courses) might not have access to the curriculum necessary for educational success. A documented history of exclusionary schooling in which ELLs were placed in peripheral programs and had limited access to rigorous content added leverage to the push for in- clusive education (Nieto, 2002; Olsen, 1997; Valdes, 2001). If the inclusion model is to be effective in granting ELLs equitable access to the curriculum, however, instruction must be altered for a multilingual audience. Techniques considered effective for English-proficient students might not render content comprehensible for students learning English (Echevarria, Vogt, \& Short, 2000). For example, classrooms that follow a traditional knowledge-transmission model of instruction represent an exclusionary learning climate for ELLs, particularly for those with low levels of English proficiency. The inadequacies of unmodified instruction or instruction designed solely for an English-proficient audience have been noted by several researchers (Echevarria et al.; Gibbons, 2002). To allow ELLs access to the curriculum, educators must adapt traditional approaches to instruction or, at a minimum, supplement their methods.

Advice for teachers regarding how they can adjust content and instruction is increasingly accessible for those who pursue it. There has been a marked surge in the number of books, journal articles, and professional development initiatives that offer teaching strategies to ELL educators. Yet, teacher views on the scope and types of modifications that they are willing to make have remained largely unexamined. Some teacher struggles to identify and implement appropriate, effective instruction for mainstreamed ELLs are apparent in recent research. For example, Gina, a high school teacher (see Reeves, 2002) was conflicted about making coursework modifications for an ELL in her 10thgrade U.S. history class. "They [ELLs] have to know the information for the end of course test. And you can't really abbreviate the amount of factual [information]" (p. 90). As Gina's comment suggests, concerns about educational equity regarding coursework modifications also might be a factor in teachers' views on effective and appropriate modifications for ELLs (Reeves, 2004; Youngs, 1999).

Attitudes toward Professional Development

Given the increase in the ELL population and the lack of training that teachers have received for working with ELLs, professional development in this area also has become a high priority for many school districts. Little research, however, has explored teacher attitudes toward that type of professional development. Clair (1995) provided a rare glimpse into three teachers' views. When given the opportunity to attend inservice workshops on methods of working with ELLs, all three of Clair's participants (Grades 4, 5, and 10 teachers) declined. One of Clair's participants believed that the workshops presented methods and materials that were inappropriate for her classroom, such as a workshop that encouraged the use of puppetry. 
The two remaining teachers, although interested in receiving materials that they could use with ELLs, believed that as experienced teachers of English-proficient students, they were already well prepared to work with ELLs. One teacher explained that, "As far as teaching goes, teaching is the same no matter what kind of kids you have" (p. 191). Clair's study, which provided data from only a small group of teachers, suggests the need for larger scale studies of educators' attitudes toward ESL professional development.

\section{Research Questions}

I used data from a large study (Reeves, 2002) of secondary teachers' experiences with ELL inclusion to examine secondary teachers' attitudes and perceptions of including ELLs in mainstream classes. The original study consisted of two parts: (a) a large-scale, 38-item survey of 279 teachers' attitudes and perceptions and (b) four case studies of secondary subject-area teachers. I reported 16 items from the survey, each representing four salient themes in teacher attitudes and perceptions of the inclusion of ELLs. The following four research questions guided this study:

1. What are teacher attitudes toward ELL inclusion in mainstream classes?

2. What are teacher attitudes toward the modification of coursework for ELLs?

3. What are teacher attitudes toward ESL professional development?

4. What are teacher perceptions of second-language acquisition processes?

\section{Instrumentation}

I used a survey to gauge teacher attitudes and perceptions of ELL inclusion. Attitudes and perceptions "... form a whole constellation of working rules about the world and reactions to it" (Sapsford, 1999, p. 141); therefore, the study of attitudes through survey research may most effectively be approached through indirect questioning of respondents' opinions, attitudes, perceptions, and beliefs. "A straightforward question can all too easily evoke a rhetorical or ideological response, and this is often not what the research requires" (p. 106). In consideration of the complexities of attitudinal survey research, I used a survey composed of multiple statements to directly and indirectly probe respondents' attitudes and perceptions of ELL inclusion.

Because I found no appropriate instrument to measure teacher attitudes and perceptions of the inclusion of ELLs, I constructed a survey instrument (see Appendix). The full survey consisted of four sections. Section A gauged teachers' strength of agreement or disagreement with 16 statements addressing attitudes toward ELL and ESL inclusion. Section B measured the frequency of teaching behaviors among teachers with ELLs in their classrooms. Section C asked participants two open-ended questions concerning benefits and challenges of ELL inclusion. Section D gathered demographic information. When I designed the survey, I relied on research findings and suggestions for further research found in relevant literature. For each category of attitude (e.g., attitudes toward inclusion), I wrote multiple statements, rather than a singular item, to gauge teachers' attitudes (see Table 1).

I measured teachers' strength of (dis)agreement with survey items with a 4-point, Likert-type scale asking respondents to read each statement and check the box that most closely represented their opinions, from 1 (strongly agree), 2 (agree), 3 (disagree), or 4 (strongly disagree). The survey instrument also collected demographic data from respondents, including subject areas, gender, years of teaching experience, native language, second-language proficiency, and types of ELL training.

The Pilot Study

I piloted the instrument with 30 middle school teachers during a routine faculty meeting in fall 2001. Middle school teachers, working in a feeder school to two of the participating high schools, comprised an appropriate pilot study population because of the similarities between middle and high school teachers' work environments. Middle and high school teachers in the district originally worked with a low incidence of ELLs. For educators in the pilot study, less than $2 \%$ (nine students) during the 2000-2001 academic year of their student population were identified as limited-English proficient. Also, the middle and high schools shared an inclusion model for ELLs; those students were placed in the mainstream for the majority of their classes. Therefore, despite working with students of younger ages, work experiences of middle school teachers were similar to those of their high school counterparts, and their reaction to the survey was a useful predictor of the survey's readability and content validity.

Validity of the Instrument

I gathered data in the pilot study to assess the readability and content validity of the survey items. Pilot study participants completed the entire survey, then answered the following questions about whether the survey allowed them to report their attitudes and perceptions of ELL inclusion accurately and fully.

1. Which, if any, items on the survey were unclear to you? Explain.

2. Which, if any, items did you find difficult to answer? Explain.

3. This survey uses a 4-point Likert-type scale, 1 strongly agree), 2 (agree), 3 (disagree), and 4 (strongly disagree). While completing the survey, did you feel that this scale adequately allowed you to express your opinion? If not, explain. 
Table 1. Teacher Attitudes toward Inclusion, Coursework Modification, Professional

Development, and Language and Language Learning

\begin{tabular}{|c|c|c|}
\hline Teacher Attitude & $M$ & $S D$ \\
\hline \multicolumn{3}{|l|}{ Inclusion } \\
\hline The inclusion of ESL students in subject-area classes creates a positive educational atmosphere. & 2.84 & 0.61 \\
\hline The inclusion of ESL students in subject-area classes benefits all students. & 2.65 & 0.70 \\
\hline \multirow{2}{*}{\multicolumn{3}{|c|}{$\begin{array}{l}\text { ESL students should not be included in general education classes until they attain a minimum } \\
\text { level of English proficiency. }\end{array}$}} \\
\hline & & \\
\hline Subject-area teachers do not have enough time to deal with the needs of ESL students. & 2.83 & 0.70 \\
\hline I would welcome the inclusion of ESL students in my class. & 2.81 & 0.62 \\
\hline \multicolumn{3}{|l|}{ Coursework modifications } \\
\hline It is a good practice to simplify coursework for ESL students. & 2.44 & 0.66 \\
\hline It is a good practice to lessen the quantity of coursework for ESL students. & 2.43 & 0.67 \\
\hline It is a good practice to allow ESL students more time to complete coursework. & 2.91 & 0.57 \\
\hline Teachers should not give ESL students a failing grade if the students display effort. & 2.30 & 0.71 \\
\hline Teachers should not modify assignments for the ESL students enrolled in subject-area classes. & 2.29 & 0.63 \\
\hline \multicolumn{3}{|l|}{ Professional development } \\
\hline I have adequate training to work with ESL students. & 1.89 & 0.74 \\
\hline I am interested in receiving more training in working with ESL students. & 2.49 & 0.74 \\
\hline \multicolumn{3}{|l|}{ Language and language learning } \\
\hline ESL students should avoid using their native language while at school. & 2.39 & 0.75 \\
\hline ESL students should be able to acquire English within two years of enrolling in U.S. schools. & 2.86 & 0.60 \\
\hline I would support legislation making English the official language of the United States. & 3.26 & 0.80 \\
\hline
\end{tabular}

4. In your opinion, which, if any, items on the survey display a bias on the part of the research? Explain.

5. Provide any additional comments that you would like to make.

Comments from the pilot study participants included (a) six requests for a neutral option on the Likert scale; (b) three comments in reference to Item 16, Section A, revealing participants' belief that English was already the official language of the United States; and (c) two requests regarding the wording of items. One respondent commented that items should be worded less "bluntly"; another respondent stated that items should be written "differently." (Neither respondent elaborated on these points or offered examples of how the items were too blunt or could be written differently.) Although a neutral opinion may have granted participants more flexibility in responding to survey items, I purposefully withheld this item from the Likert scale so that participants would make a positive or negative response to the items. Analysis of respondents' comments to the five survey questions did not reveal a pattern of misunderstanding for any item; also, respondents did not report impediments to their understanding of, or ability to respond to, survey items. These data from the pilot study indicated strong content validity for the items, so I made no alternations on the instrument.

Participants and Setting

I invited all subject-area teachers from four of the district's 12 high schools to participate in the survey that, like the pilot study, I conducted during a routine faculty meeting. The faculties chosen for participation in the study came from the four high schools with the largest population of ESL students during the 20002001 school year. School A enrolled 33 LEP students, School B enrolled 21 LEP students, School C enrolled 18 LEP students, and School D enrolled 16 LEP students. I chose high schools with the largest ESL student populations to access the largest number of teachers who had experienced the inclusion of ESL students in their classes.

I selected the participants during routine faculty meetings in January and February 2002. Of the surveys distributed to 306 teachers, 281 were returned. I rejected two of the returned surveys because they were completed by nonsubject-area teachers. I did not collect names or other identifying data from respondents, who typically completed the survey within 15 min. The participants were 279 high school subjectarea teachers from a school district located in a midsized city in the southeastern United States. The Main County school district, which included 12 high schools and over 52,000 K-12 students, was a low-incidence ELL district with $2.6 \%(1,378)$ of its population identified as non-English-language background (NELB) students. Seven hundred sixty-two (1.5\%) students were identified as LEP (Table 2). The district secondary students identified as LEP attended ESL courses for one 90-min period per day. Elementary LEP students left their mainstream classes to receive ESL instruction between one and five times per week. 
Data Analysis

I analyzed survey data descriptively. Univariate analyses of the survey data and analyses providing an "examination of the distribution of cases on only one variable at a time" (Babbie, 1990, p. 247) identified participants' attitudes and perceptions of ELL inclusion according to the strength of their (dis)agreement with the survey items. The analyses included percentages, measures of central tendency, and standard deviations.

To perform univariate analyses, I assigned a numeric value to each response in the Likert scale-1 (strongly disagree), 2 (disagree), 3 (agree), and 4 (strongly agree). I performed analysis of the numeric data with SPSS statistical software.

\section{Findings}

Demographic Information

The first demographic questions on the survey gathered information on the amount of experience that participants had with ELL inclusion. Two hundred seventeen $(77.8 \%)$ participants reported that they had experienced ELL inclusion at some point in their teaching careers. Forty-two (15.1\%) participants had not taught ELLs, and 20 (7.2\%) did not report their ELL experience. Participants who had taught ELLs had an average of two ELLs in their classrooms during the semester of the study, and their classes included an average of 14.5 ELLs over the course of their careers.

I gathered additional demographic information on the survey, including participants' subject areas, years of teaching experience, gender, native language, second-language proficiency, and language minority or ESL student training. Table 3 summarizes the frequencies and percentages of teachers' subject areas. Participants' years of teaching experience ranged from 0.5 to 40 years. Mean years of experience was 14.5. The majority of the participants, $170(60.9 \%)$, were women; 102 $(36.6 \%)$ were men; and 7 (2.6\%) were unreported. The overwhelming majority of the participants were native-English speakers (98.2\%). Only two (0.7\%) participants spoke a native language other than English. One hundred eight $(38.7 \%)$ participants reported speaking a second language, 166 (59.5\%) did not speak a second language, and $6(2.2 \%)$ participants did not respond. Of the 108 participants who reported that they spoke a second language, 46 estimated that they had attained a beginning level of proficiency in their second language, 39 estimated an intermediate level of proficiency, and 23 estimated an advanced level of proficiency. A majority of participants, $252(90.3 \%)$, had received no training to work with language-minority or ESL students. Seventeen $(6.1 \%)$ participants had received some type of training; 10 (3.6\%) participants did not respond. Fourteen of the 17 participants who had received training reported on the type of training that they received: 6 teachers had taken college coursework preparing them for teaching with language-minority students, 6 teachers had attended in-service workshops or seminars, and two teachers had experienced both types of training.

Attitudes toward Inclusion

Teachers largely held a welcoming attitude toward the inclusion of ELLs, as measured by their responses to the statement, "I would welcome the inclusion of ESL students in my class." On a Likert-type scale in which 1 = strongly disagree, 2 = disagree, $3=$ agree, and $4=$ strongly agree, a mean response of 2.81 with a standard deviation of 0.62 was reported. Seventy-two percent of respondents agreed or strongly agreed with the statement, whereas $24.3 \%$ (68) disagreed or strongly disagreed. Two hundred and nine $(75 \%)$ teachers reported that the inclusion of ELLs created a positive educational atmosphere in their classrooms, $64(23 \%)$ teachers disagreed, and $6(2.2 \%)$ teachers did not report on ELL inclusion. The mean for that item was $2.84(S D=0.61)$.

Table 2. Student Enrollment

\begin{tabular}{lccccccc} 
School & Total & \multicolumn{2}{c}{ LEP students } & \multicolumn{2}{c}{ NELB students } & \multicolumn{2}{c}{ LEP \& NELB } \\
enrollment & $n$ & $\%$ & $n$ & $\%$ & $n$ & $\%$ \\
\hline A & 1,753 & 32 & 1.8 & 33 & 1.9 & 65 & 3.7 \\
B & 1,296 & 21 & 1.6 & 21 & 1.6 & 42 & 3.2 \\
C & 1,472 & 16 & 1.1 & 16 & 1.1 & 32 & 2.2 \\
D & 2,017 & 14 & 0.7 & 18 & 0.9 & 32 & 1.6 \\
Districtwide & 52,072 & 762 & 1.5 & 616 & 1.2 & 1,378 & 2.6
\end{tabular}

Note. LEP = students identified as limited English proficient and attending English-as-a-second-language classes; NELB = students identified as non-English-language background and English proficient. Enrollment information was provided by the school district's state department of education. 
Table 3. Subject-Area Frequencies and Percentages

\begin{tabular}{lcc} 
Subject area & $f$ & $\%$ \\
\hline English & 46 & 16.5 \\
Mathematics & 43 & 15.4 \\
Science & 35 & 12.5 \\
Social studies & 32 & 11.5 \\
Vocational & 29 & 10.4 \\
World languages & 23 & 8.2 \\
Business and technology & 22 & 7.9 \\
Art and music & 18 & 6.5 \\
Health and physical education & 11 & 3.9 \\
Unreported & 20 & 7.2
\end{tabular}

Although a majority of the teachers reported that ELL inclusion created a positive education atmosphere, more than $40 \%$ (113) of respondents did not believe that all students benefited from the inclusion of ELLs in the mainstream classroom. The mean response for the item "the inclusion of ESL students in subject-area classes benefits all students" was $2.65(S D=0.70)$. Furthermore, despite the welcoming attitudes that teachers reported, strong agreement with the statement that ELLs should not be mainstreamed until the students had attained a minimum level of English proficiency was evident $(M=2.95, S D=$ $0.74)$. Two hundred nine (75\%) agreed with the statement, and $64(22.9 \%)$ disagreed. The final measure of teachers' attitudes toward the inclusion of ELLs focused on teachers' perception of time and the time demands placed on educators when ELLs enrolled in their courses. Nearly $70 \%$ (194) of the teachers reported that they did "not have enough time to deal with the needs of ESL students" ( $M$ $=2.83, S D=0.70$ ).

Attitudes toward Modification of Coursework

Teachers reported a tolerance for some coursework modifications for ELLs as demonstrated by responses to the item, "Teachers should not modify assignments for the ESL students enrolled in subject-area classes." A mean of $2.29(S D=0.63)$ indicated that although participants neither strongly agreed nor strongly disagreed with the statement, teachers had a tendency toward allowing some coursework modification. One hundred and eighty-three $(65.6 \%)$ teachers disagreed, $92(33 \%)$ teachers agreed, and four teachers did not record their responses on the statement.

Three survey items measured participants' attitudes toward specific types of coursework modification: (a) simplifying coursework, (b) lessening the quantity of coursework, and (c) allowing ELLs more time to complete coursework. Slightly more participants disagreed than agreed with the statement that the simplification of coursework was a good practice $(M=2.44, S D=0.66)$. The percentage of participants who agreed with the statement was $44.1 \%$ (123); those who disagreed represented $53.4 \%$ (149). The attitudes of participants toward lessening the quantity of coursework for ELLs were similar to attitudes toward simplifying coursework. The mean for the statement that lessening the quantity of coursework for ESL students was a good practice was $2.43(S D=0.67)$. One hundred twenty three teachers (44\%) agreed with the statement and 149 (53.4\%) teachers disagreed. Participants exhibited a more positive attitude toward allowing ELLs more time to complete coursework than toward the other two modification practices. The mean for the statement that "It is a good practice to allow ESL students more time to complete coursework" was $2.91(S D=0.57)$; $80.7 \%$ (225) of the teachers agreed with the statement and $17.9 \%(40)$ of the teachers disagreed.

For the statement "Teachers should not give ESL students a failing grade if the students display effort," a mean of 2.3 was reported $(S D=0.71)$. A slight majority $(61.7 \%)$ of participants (172) disagreed or strongly disagreed with that statement, indicating some unwillingness to allow the effort of ELLs to influence grading procedures.

Finally, more than $60 \%$ (169) of respondents did not believe that coursework modifications "would be difficult to justify to other [non-ESL] students." One hundred and seven teachers $(38.4 \%)$ reported that such modification would be difficult for them to justify. The item had a mean of $2.37(S D=0.71)$.

Attitudes toward Professional Development

A majority of respondents felt untrained to work with ELLs, yet their attitudes toward receiving more training were ambivalent. Participants generally disagreed with the statement "I have adequate training to work with ESL students." I calculated a mean of 1.89 and a standard deviation of .74 for that item. Two hundred twenty-nine teachers $(81.7 \%)$ disagreed with the statement, 49 (17.6\%) teachers agreed, and two teachers did not report on the item. A mean of $2.49(S D=0.74)$ was reported for the item "I am interested in receiving more training in working with ESL students." Approximately half (148) of the participants $(53 \%)$ were interested in receiving training in working with ESL students; 126 (45\%) participants were not interested.

Attitudes toward Language and Language Learning

I questioned respondents on their attitudes toward English and their perceptions of the utility of ESL students' first languages at school. A strong majority "would support legislation making English the official language of the United States"; $82.5 \%$ (230) teachers agreed and only 15\% (42) disagreed $(M=3.26, S D=0.80)$. Despite strong support for making English the official language, 58.4\% (163) of teachers disagreed with the item "ESL students should avoid using their native language while at school" $(M=$ $2.39, S D=0.75)$. Thirty-nine percent (109) of teachers reported that ELLs should discontinue use of their native language in school.

Finally, the survey queried teacher perceptions of the length of time that ESL students needed to acquire English proficiency. Most (71.7\%) teachers agreed that "ESL students should be able to acquire English within two years of enrolling in U.S. schools" $(M=2.86, S D=0.60)$. 


\section{Discussion}

Findings from this study are particular to its locale, yet they provide some insight into subject-area teachers' attitudes toward ELL inclusion in mainstream classrooms in the nation at large. Four findings of specific import emerged from this study:

1. A discrepancy exists between teachers' general attitudes toward ELL inclusion and their attitudes toward specific aspects of ELL inclusion.

2. Teachers expressed concern about the equitability of coursework modifications for ELLs.

3. Teachers demonstrated an ambivalence toward participating in professional development for working with ELLs.

4. Teachers are working under misconceptions about how second languages are learned.

Discrepancy in General and Specific Attitudes toward Inclusion

The secondary subject-area teachers in this study, like those in Youngs and Youngs (2001), reported a neutral to slightly positive attitude toward the inclusion of ELLs in their mainstream classrooms in general. Further analysis of teachers' attitudes toward specific aspects of inclusion, however, suggests that this self-reported, welcoming attitude may mask or accompany a reluctance to work with particular ELLs (e.g., those with very limited English proficiency). An examination of teachers' responses to those survey items designed to probe inclusion attitudes revealed some inconsistency with items that provided a more general look at inclusion attitudes. For example, on the general measures of teacher-inclusion attitudes, survey respondents largely believed that inclusion created a positive education environment (Item A1); most teachers reported that they would welcome ELLs into their classroom (Item A15). In response to specific items probing particular aspects of inclusion, teachers revealed that they were reluctant to work with ELLs who lacked a minimum level of English proficiency (Item A3) and believed that they did not have enough time to meet the needs of ELLs (Item A6). Furthermore, only slightly more than half of the teachers believed that ELL inclusion benefited all students (Item A2), in contrast to the nearly three quarters who believed that ELL inclusion created a positive education environment.

The discrepancy in general attitudes toward inclusion and attitudes toward specific inclusion aspects may be an artifact of either respondents' desire to please the researcher or to give socially acceptable answers (Alreck \& Settle, 1995). In the first case, I was introduced to all respondents at school faculty meetings as a doctoral student in ESL education. Respondents might have felt a desire to please me by providing positive responses to items such as "I would welcome the inclusion of ESL students in my classroom." Furthermore, although data were collected anonymously, respondents might have felt some pressure to provide socially acceptable responses to general statements of welcoming.
The discrepancy between general and specific inclusion attitudes also may be an indication of the complexity of teachers' thinking concerning ELL inclusion. Despite a genuinely positive attitude toward ELL inclusion, for example, educators might have reservations about teaching particular ELLs. Teachers' reluctance to work with low-proficiency ELLs may typify the complexity. Such reluctance may stem from teachers' lack of confidence and experience in working with the ELL population, an assertion supported by findings on teacher attitudes and experiences with professional development in the area of ESL. With little training for ELL inclusion and no extra planning time, teachers may quickly become frustrated and experience feelings of inadequacy, even resentment (Reeves, 2004).

Concern over program and placement options for lowproficiency ELLs has been expressed by researchers (Harklau, 1994; Lucas, 1997; Lucas et al., 1990; Valdes, 2001) and school administrators (Platt et al., 2003). Despite the concerns, inclusion of low-proficiency ELLs in mainstream classes remains a component of many school programs, particularly in those with few ELLs. Low-incidence schools, as in this study, have few ELLs by number or percentage and typically qualify for little state or federal funding to meet the needs of this population. With a shortage of funds and qualified personnel (e.g., certified ESL or bilingual teachers), those districts often rely on the immediate and full mainstreaming of ELLs at all proficiency levels. The combination of a school faculty unprepared for ELLs and a school policy of immediate mainstreaming for all ELLs, even those with low English proficiency, sets the stage for the frustration and failure of teachers and students.

The finding that many teachers were concerned that not all students benefit from ELLs in mainstream classrooms (Item A2) was especially significant with regard to inclusion attitudes. Although educators may, in theory, believe that ELL inclusion creates a positive atmosphere, in their own classrooms they may experience a different reality. In a climate of educator accountability for the learning of all students, the inclusion of ELLs can likely create a situation in which teacher attention is torn between meeting the needs of non-ESL and ESL students. The finding that many teachers did not perceive benefits for non-ESL students during ELL inclusion, in addition to teacher perception that they did not have enough time to deal with ELLs' needs (Item A6), may be indicative of a teaching force feeling overwhelmed by the demands of ELLs in the mainstream. Solutions for schools, particularly those that have a low incidence of ELLs and that are not prepared to educate them, are neither simple to conceive nor easy to generalize from setting to setting. However, recent casestudy research offers a look at a few school programs that have created workable ELL inclusion models (Fu, 2003; Schechter \& Cummins, 2003; Walqui, 2000). Some common elements in those models are (a) cohesive and comprehensive ELL intake and placement procedures, (b) staff-initiated, long-term professional development, and (c) locally devised, case-specific solutions. 
Equitability of Coursework Modifications

Findings suggest that teacher attitudes toward coursework modifications may be influenced by their concern for educational equity. That result is evident in the variance of teacher attitudes toward specific types of coursework modifications. The general attitudes of teachers toward coursework modifications (Item A11) were neutral to slightly positive, but certain types of coursework modifications were viewed as better than others. For example, granting ELLs more time to complete their coursework was more widely accepted as a good practice than was altering or abbreviating the coursework. Teachers may believe that giving ELLs extra time is a means for maintaining the integrity of coursework standards and simultaneously acknowledging ELLs' unique linguistic circumstances. Conversely, neither simplified nor reduced amounts of coursework for ELLs were considered particularly good practices. Those modifications may be untenable not only because teachers perceive that the modifications undermine the integrity of coursework standards but also because making such modifications could ultimately limit ELLs' access to the rigorous curriculum necessary for postsecondary educational opportunity (Echevarria et al., 2000; Gebhard, 2003; Reeves, 2004). Therefore, although teachers expressed support for coursework modifications, this support may depend on the perceived equitability of specific modifications.

The question of what is appropriate and equitable instruction for ELLs appears to be a pressing question for educators. Gebhard (2003), among others, asserted that appropriate, equitable instruction for ELLs is neither watered down nor unmodified. "To increase equity for English-language learners, schools must provide the support that these students need to engage in challenging contentbased learning tasks" (p. 35). Equitable instruction maintains content standards while content is presented in linguistically appropriate ways. Curricular expectations for ELLs must be the same as those for English-proficient students; high expectations are not met when instruction does not grant ELLs access to the curriculum. Linguistically appropriate instructional models are the focus of recent research into equitable instruction for ELLs. Sheltered instruction models, such as the Sheltered Instruction Observation Protocol (SIOP) developed by Echevarria and colleagues (2000), are providing promising results. The models provide linguistically modified instruction of gradelevel content to build ELLs' academic and language proficiency simultaneously. When used in mainstream courses that enroll ESL and non-ESL students, sheltered instruction techniques potentially enhance instruction for both groups of students.

Ambivalence toward Professional Development

Teachers' perception that they lacked adequate training to work with ELLs is troubling in light of the increasing number of ELLs throughout the nation. Perhaps equally troubling is the finding that nearly half of the teachers surveyed were uninterested in receiving such training.
Three possible reasons for teachers' ambivalence toward professional development, even in light of their admitted inadequacy in ESL training, have been suggested by several researchers. One explanation comes from Valdes (2001) and others who found that subject-area teachers might believe that ESL or bilingual teachers, rather than general education teachers, are primarily responsible for educating ELLs. In some instances, subject-area teachers have even refused to allow ELLs into their classes (Olsen, 1997; Valdes, 1998). The researchers argued, however, that for ELLs to have equitable access to educational opportunity, subject-area teachers must participate actively in all students' education, granting, rather than withholding, access to content.

A second explanation for teacher ambivalence is the disappointing history of professional development. Teachers have been bombarded with one-shot professional development schemes that have failed to provide the support necessary to sustain educational change and reform. Gonzalez and Darling-Hammond (1997) observed that "most teachers have experienced one or more sessions in which experts from outside the schools present ideas ... in the manner of traveling salesmen" (p. 35). Teacher cynicism may well color their attitudes toward all professional development initiatives, regardless of the subject matter. Considering teachers' history with professional development, innovative preservice and in-service training for K-12 ELL teachers should be an educational imperative.

Finally, teachers may believe, as Clair (1995) reported, that no special professional development is needed to work effectively with ELLs. In other words, professional development would be unnecessary for educators who believe that differentiated instruction for ELLs is inappropriate or ineffective.

Case studies of successful professional development initiatives for teaching ELLs highlight the importance of (a) active teacher participation in the professional development program, (b) a commitment to school-wide, longterm change, and (c) strong, ongoing university-to-school partnerships (Barnett, 2002; Fu, 2003, Gonzalez \& DarlingHammond, 1997; Milambiling, 2002; Schechter \& Cummins, 2003). Those success stories also emphasize the primacy of locally devised, context-specific solutions over the importation of solutions from other school settings.

Misconceptions Regarding Second-Language Acquisition In addition to gauging teacher attitudes toward ELL inclusion, coursework modification, and professional development, the survey gathered respondents' perceptions of second-language acquisition and attitudes toward English as the official language of the United States. A large number of teacher perceptions of how second languages are learned ran contrary to research findings in secondlanguage acquisition. Two misconceptions were evident in this study: (a) ELLs should be able to acquire English within two years and (b) ELLs should avoid using their native language as they acquire English. First, the time needed for full acquisition of a second language depends 
on a number of factors, including age, personality, environment, and first-language proficiency (see Larsen-Freeman \& Long, 1991). Although a typical time trajectory has not, or perhaps cannot, be agreed on, much evidence suggests that full proficiency, including the ability to use English in academic, as well as in social situations, may take more than 7 years (Cummins, 1979). Teacher perceptions that two years is sufficient for full-language proficiency is not supported by research; this misconception may lead teachers to faulty conclusions concerning ELLs' language ability, intelligence, or motivation.

Second, nearly $40 \%$ of respondents questioned the utility of ELLs' continued use of their first language in school. However, research has highlighted the importance of continued first-language use in developing second-language literacy (Cummins, 1981; Wong Fillmore, 1991; see also Krashen, 2003). Teachers' language-acquisition misconceptions may color their attitudes toward ELLs and ELL inclusion, leading educators to misdiagnose learning difficulties or misattribute student failure to lack of intelligence or effort. The findings suggest the importance of all ELL teachers possessing a basic understanding of second-language acquisition processes.

\section{Conclusion}

Much work remains for research that explores teacher attitudes toward the inclusion of ELLs in the mainstream, as well as the instructional implications of those attitudes. As the ELL population in the nation continues to grow, a pressing need exists for continued research in this area. In addition to further study of teacher attitudes and their impact on teaching and learning, researchers also must examine teacher education and professional development initiatives that will result in the successful inclusion of ELLs. Although the findings presented here suggest that teachers want to welcome ELLs into the mainstream, the data also reveal a teaching force struggling to make sense of teaching and learning in multilingual school environments.

\section{Notes}

1. Mainstream is a problematic term because it implies that ELLs, ESL courses, and the ESL teacher are somehow peripheral in their schools. That may not be the case as, for example, ELLs in high-incidence districts may comprise half or more of the student population. Mainstream, however, is an accurate descriptor of subject-area teachers and their courses in this school setting. ELLs comprised less than $3 \%$ of the study body, ESL courses often met in makeshift classrooms, and ESL teachers worked itinerantly, visiting a number of schools each day. In school settings throughout the United States, even schools with large numbers of ELLs, ESL courses, and ESL teachers are commonly outside the center or mainstream of school life socially, academically, and even spatially (Berube, 2000; Gitlin, Buendia, Crosland, \& Doumbia, 2003; Platt, Harper, \& Mendoza, 2003).

2. Subject-area teachers, for the purposes of this study, were those who taught core or elective classes. Subject ar- eas included mathematics, English, science, social sciences, physical education, business, music, world languages, industrial arts, and home ecology. Teachers who were not considered subject-area teachers were those who taught special needs classes (i.e., special education, gifted and talented, and ESL).

References

Alreck, P.L., \& R.B. Settle (1995). The Survey Research Handbook (2nd ed.). Chicago: Irwin.

Babbie, E. (1990). Survey Research Methods. Belmont, Calif.: Wadsworth.

Barnett, J. (2002). From the margins to the center: ESL as a whole school endeavor. In: E.F. Cochran (Ed.), Mainstreaming (pp. 7-19). Alexandria, Va.: Teachers of English to Speakers of Other Languages.

Berube, B. (2000). Managing ESL Programs in Rural and Small Urban Schools. Alexandria, Va.: Teachers of English to Speakers of Other Languages.

Clair, N. (1995). Mainstream classroom teachers and ESL students. TESOL Quarterly 29: 189-196.

Creese, A. (2002). The discursive construction of power in teacher partnerships: language and subject specialists in mainstream schools. TESOL Quarterly 36: 597-616.

Cummins, J. (1979). Cognitive-academic language proficiency, linguistic interdependence, optimal age, and some other matters. Working Papers in Bilingualism 19: 197-205.

Cummins, J. (1981). The role of primary language development in promoting educational success for language minority students. In: California State Department of Education (Ed.), Schooling and Language Minority Students: A Theoretical Framework (pp. 3-49). Los Angeles: Evaluation, Dissemination, and Assessment Center, California State University.

Cummins, J. (2000). 'This place nurtures my spirit': creating contexts of empowerment in linguistically-diverse schools. In: R. Phillipson (Ed.), Rights to Language: Equity, Power, and Education (pp. 249-258). Mahwah, N.J.: Erlbaum.

Echevarria, J., M.E. Vogt \& D.J. Short (2000). Making Content Comprehensible for English Language Learners: The SIOP Model. Needham Heights, Mass.: Allyn \& Bacon.

Fu, D. (1995). My Trouble Is My English: Asian Students and the American Dream. Portsmouth, N.H.: Heinemann.

Fu, D. (2003). An Island of English: Teaching ESL in Chinatown. Portsmouth, N.H.: Heinemann.

Gebhard, M. (2003). Getting past "see spot run." Educational Leadership 60(4): 35-39.

Gibbons, P. (2002). Scaffolding Language, Scaffolding Learning: Teaching Second Language Learners in the Mainstream Classroom. Portsmouth, N.H.: Heinemann.

Gitlin, A., E. Buendia, K. Crosland \& F. Doumbia (2003). The production of margin and center: welcoming-unwelcoming of immigrant students. American Educational Research Journal 40(1): 91-122.

Gonzalez, J.M., \& L. Darling-Hammond (1997). New Concepts for New Challenges: Professional Development for Teachers of Immigrant Youth. McHenry, Ill.: Center for Applied Linguistics.

Harklau, L. (1994). Tracking and linguistic minority students: consequences of ability grouping for second language learners. Linguistics and Education 6: 217-244.

Harklau, L. (1999). The ESL learning environment in secondary school. In: C.J. Faltis \& P.M. Wolfe (Eds.), So Much to Say: Adolescents, Bilingualism, and ESL in the Secondary School (pp. 42-60). New York: Teachers College Press.

Harklau, L. (2000). From the 'good kids' to the 'worst': representations of English language learners across educational settings. TESOL Quarterly 34: 35-67.

Johnson, K.E. (1999). Understanding Language Teaching. Toronto, Ontario, Canada: Heinle \& Heinle.

Johnson, K.E., \& P.R. Golombek (2002). Teachers' Narrative Inquiry as Professional Development. New York: Cambridge University Press. 
Kindler, A.L. (2002). Survey of States' Limited English Proficient Students and Available Educational Programs and Services: 2000-2001 Summary Report. Washington, D.C.: National Clearinghouse for English Language Acquisition and Language Instruction Educational Programs.

Krashen, S.D. (2003). Explorations in Language Acquisition. Portsmouth, N.H.: Heinemann.

Larsen-Freeman, D., \& M.H. Long (1991). An Introduction to Second Language Acquisition Research. New York: Addison Wesley Longman.

Lucas, T. (1997). Into, through, and beyond Secondary School: Critical Transitions for Immigrant Youth. McHenry, Ill.: Center for Applied Linguistics.

Lucas, T., R. Henze \& R. Donato (1990). Promoting the success of Latino language-minority students: an exploratory study of six high schools. Harvard Educational Review 60: 315-340.

Mace-Matluck, B.J., R. Alexander-Kasparik \& R.M. Queen (1998). Through the Golden Door: Instructional Approaches for Immigrant Adolescents with Limited Schooling. McHenry, Ill.: Center for Applied Linguistics.

Milambiling, J. (2002). Good neighbors: mainstreaming ESL students in the rural Midwest. In: E.F. Cochran (Ed.), Mainstreaming (pp. 2130). Alexandria, Va.: Teachers of English to Speakers of Other Languages.

National Center for Education Statistics. (2002). School and Staffing Survey 1999-2000: Overview of the Data for Public, Private, Public Charter and Bureau of Indian Affairs Elementary and Secondary Schools. Washington, D.C.: U.S. Department of Education.

Nieto, S. (2002). Language, Culture, and Teaching: Critical Perspectives for a New Century. Mahwah, N.J.: Erlbaum.

Olsen, L. (1997). Made in America: Immigrant Students in Our Public Schools. New York: The New Press.

Platt, E., C. Harper \& M.B. Mendoza (2003). Dueling philosophies: inclusion or separation for Florida's English language learners. TESOL Quarterly 37: 105-133.
Reeves, J. (2002). Secondary Teachers' Attitudes and Perceptions of the Inclusion of ESL Students in Mainstream Classes. (Doctoral dissertation, University of Tennessee, 2002). Dissertation Abstracts International 63: 8 .

Reeves, J. (2004). 'Like everybody else': equalizing educational opportunity for English language learners. TESOL Quarterly 38: 43-66. Sapsford, R. (1999). Survey Research. Thousand Oaks, Calif.: Sage.

Schechter, S.R., \& J. Cummins (2003). Multilingual Education in Practice: Using Diversity as a Resource. Portsmouth, N.H.: Heinemann.

Schmidt, M.A. (2000). Teachers' attitudes toward ESL students and programs. In: S. Wade (Ed.), Inclusive Education: A Casebook and Readings for Prospective and Practicing Teachers (pp. 121-128). Mahwah, N.J.: Erlbaum.

U.S. Census Bureau. (2000). Projected Migration by Race and Hispanic Origin, 1999 to 2100. Washington, D.C.: National Projections Program.

Valdes, G. (1998). The world outside and inside schools: language and immigrant children. Educational Researcher 27(6): 4-18.

Valdes, G. (2001). Learning and Not Learning English: Latino Students in American Schools. New York: Teachers College Press.

Verplaetse, L.S. (1998). How content teachers interact with English language learners. TESOL Journal 7: 24-28.

Vollmer, G. (2000). Praise and stigma: Teachers' constructions of the 'typical ESL student.' Journal of Intercultural Studies 21(1): 53-66.

Walqui, A. (2000). Access and Engagement: Program Design and Instructional Approaches for Immigrant Students in Secondary Schools. McHenry, Ill.: Center for Applied Linguistics.

Wong Fillmore, L. (1991). When learning a second language means losing the first. Early Childhood Research Quarterly 6: 323-346.

Youngs, C.S. (1999). Mainstreaming the Marginalized: Secondary Mainstream Teachers' Perceptions of ESL Students. (Doctoral dissertation, University of North Dakota, Grand Forks 1999). Dissertation Abstracts International 60: 6.

Youngs, C.S., \& G.A. Youngs, Jr. (2001). Predictors of mainstream teachers' attitudes toward ESL students. TESOL Quarterly 35: 97-120.

Appendix

English-as-a-second-language (ESL) Students in Mainstream Classrooms

A Survey of Teachers

Section A

Please read each statement and place a check in the box that best describes your opinion.

Strongly

Disagree

1. The inclusion of ESL students in subject-area classes creates a positive educational atmosphere.

2. The inclusion of ESL students in subject-area classes benefits all students.

3. ESL students should not be included in general education classes until they attain a minimum level of English proficiency.

4. ESL students should avoid using their native language while at school.

5. ESL students should be able to acquire English within two years of enrolling in U.S. schools.

6. Subject-area teachers do not have enough time to deal with the needs of ESL students.

7. It is a good practice to simplify coursework for ESL students.

$\begin{array}{llll}\square & \square & \square & \square \\ \square & \square & \square & \square \\ \square & \square & \square & \square \\ \square & \square & \square & \square \\ \square & \square & \square & \square \\ \square & & \square & \\ \square & \square & \square & \square \\ & \square & \square & \square\end{array}$


Appendix - Continued

8. It is a good practice to lessen the quantity of coursework for ESL students.

9. It is a good practice to allow ESL students more time to complete coursework.

10. Teachers should not give ESL students a failing grade if the students display effort.

11. Teachers should not modify assignments for the ESL students enrolled in subject-area classes.

12. The modification of coursework for ESL students would be difficult to justify to other students.

13. I have adequate training to work with ESL students.

14. I am interested in receiving more training in working with ESL students.

15. I would welcome the inclusion of ESL students in my class.

16. I would support legislation making English the official language of the United States.

$\begin{array}{llll}\square & \square & \square & \square \\ \square & \square & \square & \square \\ \square & \square & \square & \square \\ \square & \square & \square & \square \\ \square & \square & \square & \square \\ \square & \square & \\ \square & \square & \square & \square \\ \square & \square & \square & \square \\ & \square & \square & \square\end{array}$

1. Have you ever had an ESL student enrolled in your classes? $\square$ Yes $\square$ No (If no, please skip to Section C.)

2. How many ESL students were enrolled in your classes during this (2001-2002) school year?

3. Approximately how many ESL students have enrolled in your classes throughout your teaching career?

Section B

Which, if any, of the following are descriptive of your classes when ESL students are enrolled? Please indicate the extent to which each of the following apply in your classes.

Seldom Some of Most or all or never the time of the time

1. I allow ESL students more time to complete their coursework.

2. I give ESL students less coursework than other students.

3. I allow an ESL student to use her/his native language in my class.

4. I provide materials for ESL students in their native languages.

5. Effort is more important to me than achievement when I grade ESL students.

Impact of Inclusion

6. The inclusion of ESL students in my classes increases my workload.

7. ESL students require more of my time than other students require.

8. The inclusion of ESL students in my class slows the progress of the entire class.

Teacher Support

9. I receive adequate support from school administration when ESL students are enrolled in my classes.

10. I receive adequate support from the ESL staff when ESL students are enrolled in my classes.

11. I conference with the ESL teacher.

$\begin{array}{lll}\square & \square & \square \\ \square & \square & \square \\ \square & \square & \square \\ \square & \square & \square \\ & & \\ \square & \square & \square \\ \square & \square & \square \\ \square & \square & \square \\ & & \\ & & \\ \square & \square & \square \\ \square & \square & \square \\ \square & \square & \square\end{array}$


Appendix-Continued

Section C

1. Please list what you consider to be the greatest benefits of including ESL students in subject-area classes:

2. Please list what you consider to be the greatest challenges of including ESL students in subject-area classes:

Section D

Please answer the following questions. Your answers will assist in the categorization of the responses.

1. What subject area(s) do you teach? (if more than one, please list your primary area first)

2. How many years have you been a public or private school teacher (including this year)?

3. Please indicate your gender. $\quad \square$ Male $\quad \square$ Female

4. Is English your native language?

5. Do you speak a second language?

If yes, please estimate your highest ability level attained:

$\checkmark$ beginner $\quad \square$ intermediate $\quad \square$ advanced

6. Have you received training in teaching language-minority/ESL students? Yes No

If yes, please describe the type of training, (i.e., inservice workshop, college coursework)

Comments: Please write any additional comments you may have concerning the inclusion of ESL students in subject-area classes.

Thank you for completing this survey. 